NASA/TM-2002-211510

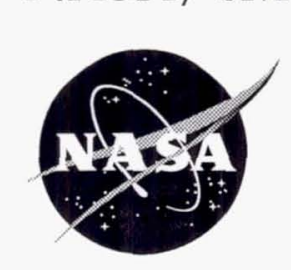

\title{
MEMS, Ka-Band Single-Pole Double-Throw (SPDT) Switch for Switched Line Phase Shifters
}

Maximilian C. Scardelletti, George E. Ponchak, and Nicholas C. Varaljay Glenn Research Center, Cleveland, Ohio 
Since its founding, NASA has been dedicated to the advancement of aeronautics and space science. The NASA Scientific and Technical Information (STI) Program Office plays a key part in helping NASA maintain this important role.

The NASA STI Program Office is operated by Langley Research Center, the Lead Center for NASA's scientific and technical information. The NASA STI Program Office provides access to the NASA STI Database, the largest collection of aeronautical and space science STI in the world. The Program Office is also NASA's institutional mechanism for disseminating the results of its research and development activities. These results are published by NASA in the NASA STI Report Series, which includes the following report types:

- $\quad$ TECHNICAL PUBLICATION. Reports of completed research or a major significant phase of research that present the results of NASA programs and include extensive data or theoretical analysis. Includes compilations of significant scientific and technical data and information deemed to be of continuing reference value. NASA's counterpart of peerreviewed formal professional papers but has less stringent limitations on manuscript length and extent of graphic presentations.

- TECHNICAL MEMORANDUM. Scientific and technical findings that are preliminary or of specialized interest, e.g., quick release reports, working papers, and bibliographies that contain minimal annotation. Does not contain extensive analysis.

- CONTRACTOR REPORT. Scientific and technical findings by NASA-sponsored contractors and grantees.
- CONFERENCE PUBLICATION. Collected papers from scientific and technical conferences, symposia, seminars, or other meetings sponsored or cosponsored by NASA.

- SPECIAL PUBLICATION. Scientific, technical, or historical information from NASA programs, projects, and missions, often concerned with subjects having substantial public interest.

- TECHNICAL TRANSLATION. Englishlanguage translations of foreign scientific and technical material pertinent to NASA's mission.

Specialized services that complement the STI Program Office's diverse offerings include creating custom thesauri, building customized data bases, organizing and publishing research results ... even providing videos.

For more information about the NASA STI Program Office, see the following:

- Access the NASA STI Program Home Page at http://www.sti.nasa.gov

- E-mail your question via the Internet to help@sti.nasa.gov

- Fax your question to the NASA Access Help Desk at 301-621-0134

- Telephone the NASA Access Help Desk at 301-621-0390

- Write to:

NASA Access Help Desk

NASA Center for AeroSpace Information 7121 Standard Drive

Hanover, MD 21076 


\title{
MEMS, Ka-Band Single-Pole Double-Throw (SPDT) Switch for Switched Line Phase Shifters
}

\author{
Maximilian C. Scardelletti, George E. Ponchak, and Nicholas C. Varaljay \\ National Aeronautics and Space Administration \\ Glenn Research Center \\ Cleveland, Ohio 44135 \\ E-mail: m.scardelletti@grc.nasa.gov
}

\begin{abstract}
Ka-band MEMS doubly anchored cantilever beam capacitive shunt devices are used to demonstrate a MEMS SPDT switch fabricated on high resistivity silicon (HRS) utilizing finite ground coplanar waveguide (FGC) transmission lines. The SPDT switch has an insertion loss (IL), return loss (RL), and isolation of $0.3 \mathrm{~dB}, 40 \mathrm{~dB}$, and $30 \mathrm{~dB}$, respectively at Ka-band.
\end{abstract}

\section{Introduction}

Traditionally, solid-state electronic devices such as GaAs MESFETs and PIN diodes have been used to implement SPDT switching networks that are required for switched line phase shifters in phased array antennas. While these devices have performed well and enabled great leaps in radar and communication technologies, they have several problems. They rely on control of current through a semiconductor junction or a metal/semiconductor junction, and there is a resistive loss associated with charge flow that consumes substantial DC and RF power. This consumed power generates heat that must be dissipated, which adds to the system size and complexity. Lastly, linearity is required for modern, wide band communication systems that must process signals with a wide dynamic range, but transistors and diodes are nonlinear devices.

RF/microwave MicroElectroMechanical Systems (MEMS) based devices were first demonstrated by Larson in 1991 [1] as an alternative to solid-state devices for SPDT switches. Since that first paper, several variations of RF MEMS devices have been demonstrated including rotary switches [1], single supported cantilever metal-to-metal contact SPST switches [2], double supported cantilever capacitive SPST switches [3,4], and SPDT switches [5]. All of these MEMS structures have demonstrated substantially improved RF characteristics such as linearity, negligible power consumption, decreased insertion loss and improved isolation.

The SPDT switch described in this paper utilizes MEMS LC devices and $\lambda \mathrm{g} / 4$ transmission line sections to achieve the desired resonance and response at the design frequency of $26.5 \mathrm{GHz}$. The SPDT switch utilizing MEMS LC devices described in this paper exhibits greatly improved $\mathrm{RF} /$ microwave characteristics, which can make it a desired alternative to conventional GaAs MESFETs and PIN diodes SPDT switching networks. 


\section{MEMS LC Shunt Device}

The MEMS devices utilized in the SPDT switch described in this paper are doubly anchored cantilever beams with three capacitive sections separated by two high inductive segments as seen in Figure 1. MEMS devices incorporating capacitivelinductive sections have been demonstrated $[6,7]$. This type of MEMS structure allows the switch to be designed for minimum $\mathrm{IL}$ and maximum isolation over a wide frequency range. Finite ground coplanar waveguide is used as the transmission line because the narrow width of the FGC transmission lines enable the MEMS cantilever to extend over the entire transmission line with no physical contact between the cantilever and the FGC. This enables the MEMS bias to be applied to the cantilever itself while the FGC line is held at ground or a small potential required to bias other electronic components

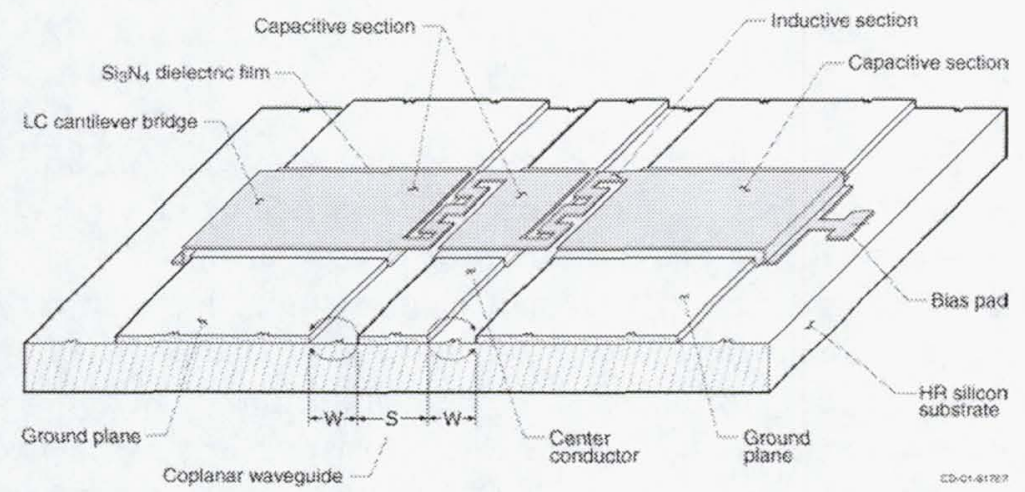

Figure1. MEMS LC shunt device implemented on FGC.

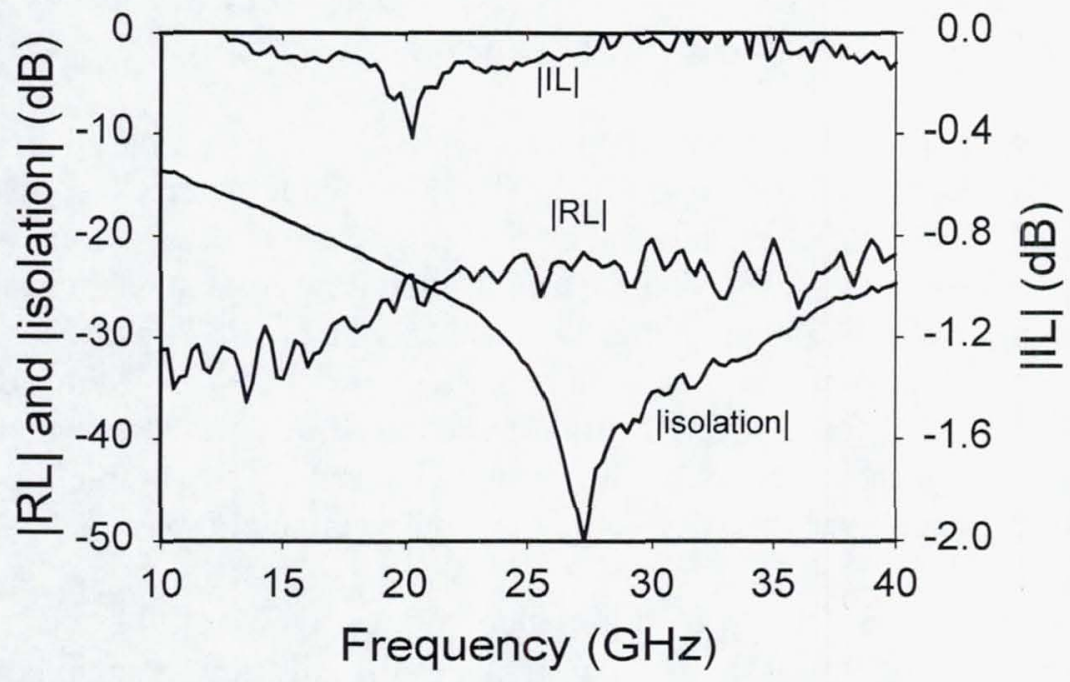

Figure 2: Measured characteristics of MEMS LC device.

The dielectric used to prevent the cantilever from making direct contact with the FGC line is silicon nitride $\left(\mathrm{Si}_{3} \mathrm{~N}_{4}\right)$, which has a dielectric constant of 8.5 
and thickness of $1000 \AA$. The doubly anchored bridge and the FGC lines are fabricated with standard IC processing procedures. The switch is formed by gold plating; the thickness of the gold plated bridge is approximately $1.7 \mu \mathrm{m}$. The MEMS LC devices as well as the SPDT switch were characterized with the HP $8510 \mathrm{C}$ Vector Network Analyzer (VNA) and Multical calibration software developed by the National Institute of Standards and Technology (NIST). The MEMS device requires a 30-volt peak-to-peak $1000 \mathrm{~Hz}$ AC square wave signal to achieve actuation. The measured characteristics of the MEMS LC device are shown in Figure 2, where it is seen that the IL, RL, and Isolation are $0.11 \mathrm{~dB}, 23 \mathrm{~dB}$, and $45 \mathrm{~dB}$, at $26.5 \mathrm{GHz}$, respectively.

III. MEMS Ka-Band Single-Pole Double-Throw (SPDT) switch

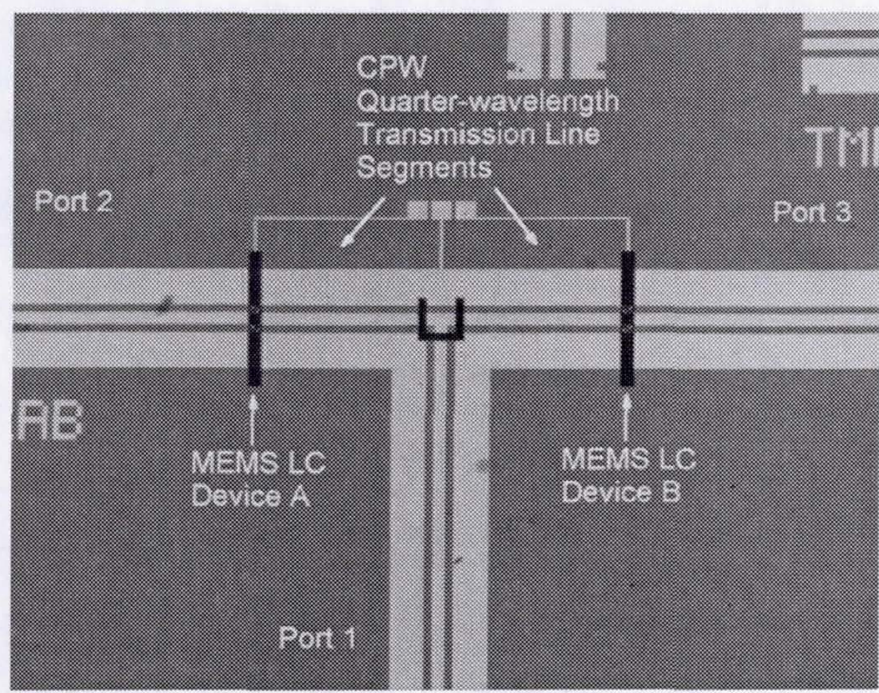

Figure 3. Microphotograph of the SPDT switch.

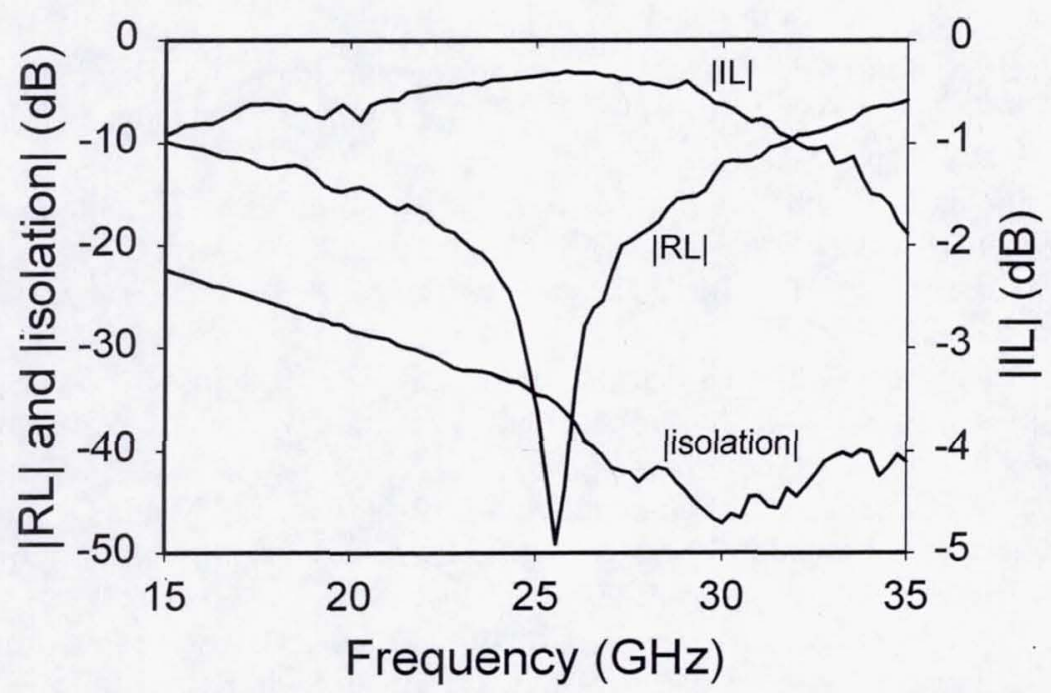

Figure 4: Measured characteristics of MEMS SPDT switch. 
The SPDT switch designed in this paper is illustrated in Figure 3. The SPDT switch is a 3-port device with two LC MEMS structures placed a quarterwavelength from the center of the $\mathrm{T}$-junction as seen in the figure. Distancing the MEMS LC devices a quarter wavelength from the center of the T-junction enables the virtual short realized from MEMS actuation to be transformed to an open at the T-junction thus blocking nearly all the signal from passing to that port. The measured results for the SPDT switch can be seen in Figure 4. The SPDT has a minimum IL, maximum RL, and maximum Isolation of $0.3 \mathrm{~dB}, 40 \mathrm{~dB}$, and $30 \mathrm{~dB}$, respectively. The MEMS LC devices and the SPDT switch were designed to operate at $26.5 \mathrm{GHz}$, but due to the $\mathrm{Si}_{3} \mathrm{~N}_{4}$ layer being deposited slightly thicker than designed the isolation is actually greatest at $30 \mathrm{GHz}$, as seen in Figure 4.

\section{Conclusion}

A SPDT switch incorporating MEMS LC structures has been reported. The performance of the SPDT switch is excellent and illustrates enhanced $\mathrm{RF} /$ microwave characteristic and performance, which makes it a desired alternative to conventional GaAs MESFETs and PIN diodes SPDT switching networks employed in switched line phase shifters for phased array antennas.

\section{References}

[1] L. E. Larson, R. H. Hackett, M. A. Melendes, R. F. Lohr, "Micromachined microwave actuator (MIMAC) technology- a new tuning approach for microwave integrated circuits," IEEE 1991 Microwave and Millimeter-Wave Monolithic Circuits Symposium Digest, Boston, MA, June 10-11, 1991, pp. 27-30.

[2] D. Hyman, A. Schmitz, B. Warneke, T. Y. Hsu, J. Lam, J. Brown, J. Schaffner, A. Walston, R. Y. Loo, G. L. Tangonan, M. Mehregany, and J. Lee, "GaAscompatible surface-micromachined RF MEMS switches," Electronics Letters, Vol. 35, No. 3, pp. 224-225, Feb. 4, 1999.

[3] S. P. Pacheco and L. P. B. Katehi, "Microelectromechanical K-Band switching circuits," $29^{\text {th }}$ European Microwave Conference Digest, Munich, Germany, October 5-7, 1999, pp. 45-48.

[4] G. E. Ponchak, R. N. Simons, M. Scardelletti, and N. C. Varaljay, "Finite ground coplanar waveguide shunt MEMS switches for switched line phase shifters," $30^{\text {th }}$ European Microwave Conference Dig., Vol. 1, Paris, France, Oct. 26, 2000, pp. 252-255.

[5] Sergio P. Pacheco, Dimitrios Peroulis and Linda P. B. Katehi, "MEMS SinglePole Double-Throw (SPDT) X and K-Band Switching Circuits." IEEE MTT-S International Microwave Symposium Digest, 2001.

[6] D. Peroulis, S. Pacheco, K. Sarabandi, and L. P. B. Katehi, "Mems Devices for High Isolation and Tunable Filtering." IEEE MTT-S International Microwave Symposium Digest, 2000, page(s): 1217-1220.

[7] Jae Y. Park, Geun H. Kim, Ki W. Chung, and Jong U. Bu, "Monolithically Integrated Micromachined RF MEMS Capacitive Switches." Sensors and Actuators, 2001, page(s): 88-94. 